\title{
The Influence of Thermal Radiation on Body \\ Temperature, Cardiorespiratory Activity and \\ Meat Productivity of Growing Pigs Kept \\ at a Constant Temperature of $30^{\circ} \mathrm{C}$
}

\author{
Tadashi Yoshimoto, Toshio Tanaka and Ko Mimura \\ School of Veterinary Medicine, Azabu University,
}

Sagamihara-shi 229

(Received December 2, 1983)

\begin{abstract}
The influence of a radiant heat load upon growing pigs kept at a constant temperature of $30^{\circ} \mathrm{C}$ was studied using $30-40 \mathrm{~kg}$ Landrace piglets fed ad libitum. Four piglets were used for Experiment 1, and six for Experiment II. In each experiment, the piglets were divided into two groups; one group was kept at a constant temperature of $30^{\circ} \mathrm{C}$ as the control group, another at the same temperature but was subjected to a load of radiant heat $\left(500 \mathrm{kcal} / \mathrm{m}^{2} \cdot \mathrm{hr}\right)$ using an infrared heater for 6 hours a day. The average rectal temperature of the control group was $39.8^{\circ} \mathrm{C}$, while that of the radiated group was $40.7^{\circ} \mathrm{C}$, showing a significantly higher temperature $(\mathrm{P}<0.01)$. The respiration rates for the two groups were 110 and 164 , respectively $(P<0.05)$. There was no significant difference in the heart rate between the two groups. Daily weight gains were poor in both groups, the latter being significantly poorer $(P<0.05)$. The feed intake was similar in both groups. It was concluded that thermal radiation added to the environment at a constant temperature of $30^{\circ} \mathrm{C}$ did exert adverse effects upon growing pigs.

Jpn. J. Zootech. Sci., 55 (6): 416-422, 1984
\end{abstract}

Heat environment is composed of such factors as air temperature, air humidity, air movement and radiation. These factors exert their combined influence upon the productivity of livestock.

Many researchers have reported the effects of these factors on pigs (HeItman ${ }^{1}$,

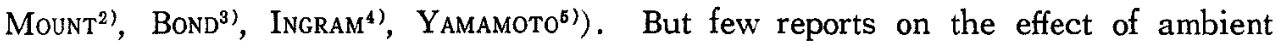
temperature with a load of radiant heat upon the physiological and productive responses of pigs have been published.

STONE and $\mathrm{HEAP}^{8)}$ investigated the growth rate, efficiency and thermal balance of pigs accommodated under three different housing conditions during summer in Southern Australia (mean daily maximum temperature, near $29^{\circ} \mathrm{C}$ ). Housed pigs grew at a similar rate to those in an outside pen with a wallow and shelter, and both groups utilized food with similar efficiency. A group accommodated in an outside pen with a wallow but without shelter grew at a significantly slower rate $(347 \mathrm{~g} /$ day $)$ with a lower efficiency of food conversion than that of either of the other two groups.

There are considerable differences in air temperature among the regions of Japan as the long archipelago stretches from the northeast down to the southwest. Especially to be poined out is that air temperature very often exceeds $30^{\circ} \mathrm{C}$ and livestock 
is reared in environments with such high temperatures in the Kanto district and southward. Under this environment, not only the high temperature but also the radiant heat exert adverse effects on housed livestock.

Minowa et al. ${ }^{7)}$ reported that, in Kagawa Prefecture, western Japan, the air temperature in and around the pens and barns in summer registered $27-33.9^{\circ} \mathrm{C}$ and that temperatures above $30^{\circ} \mathrm{C}$ were marked in 12 out of 18 observations. The temperature of the roof of a piggery was as high as approximately $50^{\circ} \mathrm{C}$. They further reported that the amount of downward radiant heat in the pens was $400-500 \mathrm{kcal} / \mathrm{m}^{2} \cdot \mathrm{hr}$. The experiments we report here were planned to clarify the influence of a radiant heat load in summer in Japan upon the body temperature, cardiorespiratory activity and meat productivity of growing pigs.

\section{Materials and Methods}

Landrace piglets of Ibaragi-Rose Line procured from Zen-no Higashi-Nippon Pig Farm were employed. Two experiments were carried out: Experiment I was conducted in an environment-controlled chamber $\left(30 \pm 1^{\circ} \mathrm{C}\right.$ and $60-70 \%$ of relative humidity, air movements $0.04-0.36 \mathrm{~m} / \mathrm{sec}$.) at Azabu University, and Experiment II was conducted in an environment-controlled chamber $\left(30 \pm 0.5^{\circ} \mathrm{C}\right.$ and $60 \%$ of relative humidity) at Tokyo University of Agriculture and Technology. Four littermate piglets were used for Experiment I, which lasted for 35 days; six piglets from 3 litters were used for Experiment II, and the term for the experiment was 21 days.

The littermates were divided into two groups. One group was kept at a constant temperature of $30^{\circ} \mathrm{C}$ (control), while the other was kept at the same temperature but subjected to a load of radiant heat using infrared heaters. A heat-insulating board of glass wool with a thickness of $100 \mathrm{~mm}$ was erected in the middle of the chamber, and two (Exp. I) or three (Exp. II) piglets were kept individually in a crate on both sides of the board. The radiant heat was provided by using two infrared heaters (Pig Heater Dan, 250 W) suspended over a piglet for 6 hours from 10;00 up to 16:00. The amount of radiant heat was $500 \mathrm{kcal} / \mathrm{m}^{2} \cdot \mathrm{hr}$ on the skin of the upper part of the body of lying pigs.

All the piglets were fed ad libitum with feed (DCP: $12.9 \%$, TDN: $70.4 \%$ ) formulated for performance tests on meat production of pigs. The items determined were daily weight gain, daily feed intake and feed conversion ratio as the productive responses, and rectal temperature, respiration rate and heart rate as the physiological responses. Air temperature, air humidity, air movement and amount of radiant heat load were determined as the environmental conditions of piggeries.

The respiration rate was determined by recording the electric resistance due to the expansion and contraction of graphite packed in a rubber tube tied round the abdomen. The heart rate was determined with a Biophysiograph (NEC San-ei Instruments, Ltd.) using needle electrodes attached to the skin of the pigs. Respiration rate and heart rate were recorded at least 6 times on a chart paper for $60 \mathrm{sec}$. each time. The rectal temperature was determined and recorded with a thermister 
thermometer inserted approximately $10 \mathrm{~cm}$ deep into the anus. The recording was continued until a stable line was obtained. The thermal environments were determined with Assman's Aspiratory Psychrometer, Kata thermometer and Net radiometer of CN-11 A (Eko Instruments Trading Co., Ltd.).

The productive responses were observed once a week, and the physiological responses twice a week. The observations were made from 14:00 to 15:00 every time. The heart rate was not measured in Experiment II.

\section{Results}

The data for physiological and productive responses in Experiment I and Experiment II are shown in Table 1 and Table 2, respectively. In Experiment I, daily weight gain was generally poor in all pigs. Particularly, the group with a load of radiant heat showed even lower weight gain than the control group ( $89 \%$ of that of the control group). Daily feed intake was uniformly low at $30^{\circ} \mathrm{C}$ regardless of irradiation. The rectal temperature was $39.6^{\circ} \mathrm{C}$ to $39.7^{\circ} \mathrm{C}$ in the control pigs, while the figure was higher than $40^{\circ} \mathrm{C}$ in both pigs with a load of radiant heat. Respiration rate was high in all pigs, but the average rate was slightly higher in the group with radiant heat than in the control group.

Table 1. Physiological and productive responses of pigs kept at a constant temperature of $30^{\circ} \mathrm{C}$ with or without addition of radiant heat load in Experiment $\mathrm{I}$.

\begin{tabular}{lrrrr}
\hline & \multicolumn{2}{c}{$30^{\circ} \mathrm{C}$} & \multicolumn{2}{c}{$30^{\circ} \mathrm{C}$ +radiant heat } \\
\cline { 2 - 5 } & \multicolumn{1}{c}{ No. 3} & No. 4 & No. 1 & No. 2 \\
\hline Initial body weight (kg) & 38.8 & 32.2 & 38.0 & 36.2 \\
Daily weight gain (g) & 469 & 491 & 414 & 440 \\
Daily feed intake (g) & 1529 & 1446 & 1426 & 1426 \\
Feed conversion ratio & 3.26 & 2.94 & 3.44 & 3.24 \\
Rectal temperature ( $\left.{ }^{\circ} \mathrm{C}\right)$ & $39.7 \pm 0.18$ & $39.6 \pm 0.37$ & $40.5 \pm 0.27$ & $40.4 \pm 0.36$ \\
Respiration rate (per min.) & $120 \pm 41$ & $148 \pm 28$ & $149 \pm 33$ & $165 \pm 33$ \\
Heart rate (per min.) & $88 \pm 5$ & $97 \pm 8$ & $100 \pm 21$ & $104 \pm 11$ \\
\hline
\end{tabular}

The amount of radiant heat was $500 \mathrm{kcal} / \mathrm{m}^{2} \cdot \mathrm{hr}$. Air movements by Kata thermometer shown at $0.04-0.36 \mathrm{~m} / \mathrm{sec}$.

Table 2. Physiological and productive responses of pigs kept at a constant temperature of $30^{\circ} \mathrm{C}$ with or without addition of radiant heat load in Experiment II.

\begin{tabular}{|c|c|c|c|c|c|c|}
\hline & \multicolumn{3}{|c|}{$30^{\circ} \mathrm{C}$} & \multicolumn{3}{|c|}{$30^{\circ} \mathrm{C}+$ radiant heat } \\
\hline & No. 110 & No. 64 & No. 100 & No. 98 & No. 65 & No. 111 \\
\hline Initial body weight $(\mathrm{kg})$ & 39.4 & 44.3 & 44.0 & 46.3 & 43.5 & 39.0 \\
\hline Daily weight gain (g) & 414 & 448 & 319 & 329 & 381 & 367 \\
\hline Daily feed intake (g) & 1505 & 1505 & 1689 & 1572 & 1390 & 1611 \\
\hline Feed conversion ratio & 3.63 & 3.36 & 5.29 & 4.78 & 3.65 & 4.39 \\
\hline Rectal temperature $\left({ }^{\circ} \mathrm{C}\right)$ & $\begin{array}{r}39.8 \\
\pm 0.34\end{array}$ & $\begin{array}{r}40.0 \\
\pm 0.34\end{array}$ & $\begin{array}{r}39.7 \\
\pm 0.32\end{array}$ & $\begin{array}{r}40.5 \\
\pm 0.25\end{array}$ & $\begin{array}{r}41.0 \\
\pm 0.54\end{array}$ & $\begin{array}{r}40.9 \\
\pm 0.90\end{array}$ \\
\hline Respiration rate (per min.) & $71 \pm 22$ & $99 \pm 16$ & $93 \pm 29$ & $208 \pm 15$ & $168 \pm 33$ & $128 \pm 40$ \\
\hline
\end{tabular}


In Experiment II, both physiological and productive responses showed a similar tendency. The daily weight gain was low, the respiration rate was high and panting was noted in the group with the load of radiant heat.

The data obtained from Experiment I and Experiment II were summarized as demonstrated in the Figure for the physiological and productive responses. Data for pig No. 100 in the $30^{\circ} \mathrm{C}$ group were omitted for poor growth ${ }^{8}$. The daily weight gain was poor in both groups, giving a significantly lower $(P<0.05)$ value in the group

$/ \mathrm{min}$.
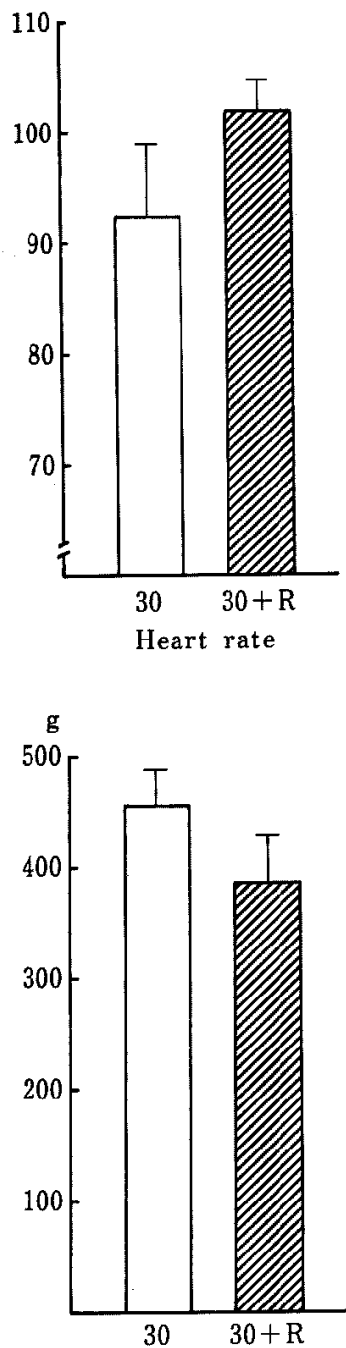

Daily weight gain ${ }^{11}$
$/ \min$.

200

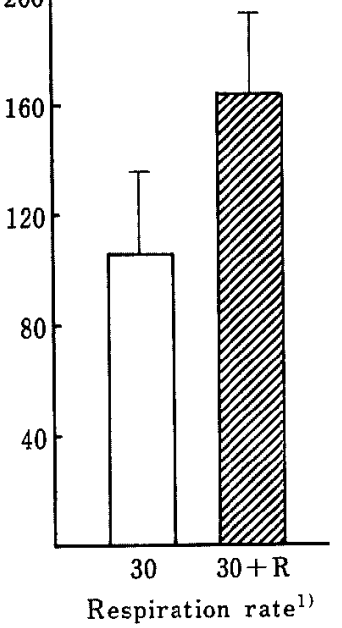

$\mathrm{kg}$

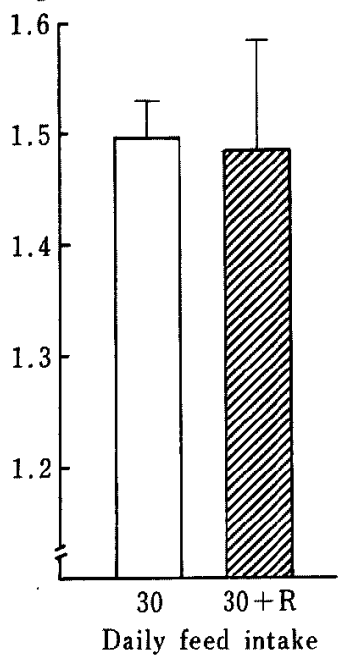

${ }^{\circ} \mathrm{C}$
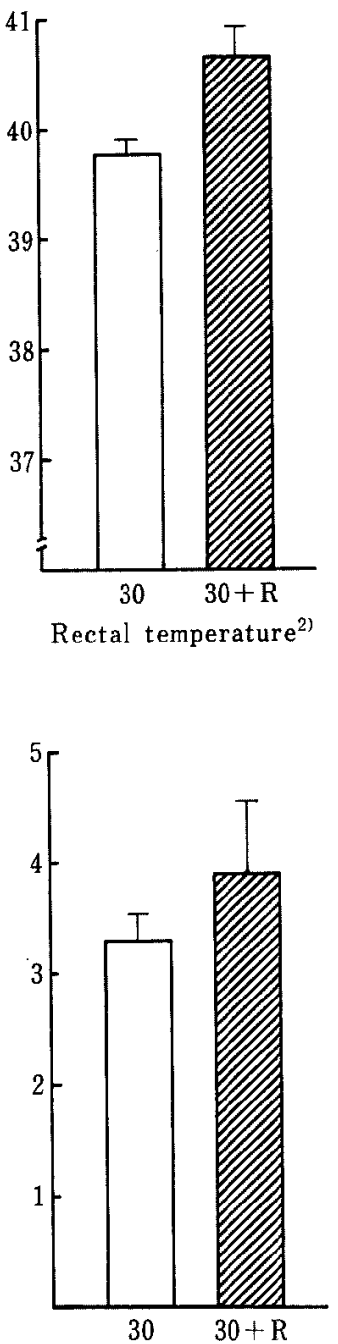

Feed conversion ratio

Fig. Influence of thermal radiation on physiological and productive responses of pigs.

30: The group at a constant temperature of $30^{\circ} \mathrm{C}, 30+\mathrm{R}$ : The group at a constant temperature of $30^{\circ} \mathrm{C}$ with radiant heat load. The vertical lines show the standard deviation for each group.

1): There is significant difference at the $5 \%$ level of probability between the two groups.

2): There is significant difference at the $1 \%$ level of probability between the two groups. 
with a load of radiant heat. The daily feed intake was similar in both groups, showing no appreciable difference. The feed conversion ratio tended to be poorer in the group with a load of radiant heat, but there was no statistical significance. The rectal temperature of the irradiated group was $40.4^{\circ} \mathrm{C}$, which was significantly higher $(\mathrm{P}<0.01)$ than that of the control group. The respiration rate of the group with a load of radiant heat was significantly higher $(\mathrm{P}<0.05)$ than that of the control group. The heart rate was $10 \%$ higher in the group with radiant heat than in the control group.

\section{Discussion}

On the influence of radiant heat

In this study, the daily weight gain was extremely poor for pigs reared in the environment of a constant temperature of $30^{\circ} \mathrm{C}$ with an additional load of radiant heat. It is considered that their energy metabolism was accelerated because the body tem. perature was beyond control by physical regulation mechanisms. This was confirmed by the fact that thermal panting was noted and rectal temperature showed above $40^{\circ} \mathrm{C}$. Accordingly, the daily weight gain and the feed conversion rate were poorer in the irradiated group than the control group although the feed intake was similar in both groups.

The authors ${ }^{9)}$ previously examined the performance of growing pigs in summer in Hokkaido, North Japan, and in Kyushu, South Japan. In Hokkaido, the physiological and productive responses were normal in the natural heat environment with or without addition of a load of radiant heat. In Kyushu, the irradiated group showed higher rectal temperature and poorer daily weight gains than the group kept in natural environment.

These results together with the present data suggest that a load of radiant heat does not influence the productivity of pigs when they are reared in the natural environment as long as the mean maximum air temperature is under $26^{\circ} \mathrm{C}$, as in Hokkaido. However, it is considered that thermal radiation added to an environment with a high temperature of $29^{\circ} \mathrm{C}^{6}$ ) or higher, as in Kyushu, exerts appreciably adverse effects upon the productivity of pigs.

GRIFFIN and VARDAMAN ${ }^{10)}$ reported that chicks grown in an ambient temperature varying in a cycle between 22.2 and $34.0^{\circ} \mathrm{C}$ and subjected to the $13.8 \mathrm{cal} / \mathrm{cm}^{2} \cdot \mathrm{hr}$ additional radiant heat energy, had a significantly lower weight gain and poorer feed conversion than the control groups without the radiant energy. Similar results were obtained by REECE et al. ${ }^{11}$.

It was observed that the productivity of pigs was controlled by slight differences in environment conditions in the thermal environment between $27-30^{\circ} \mathrm{C}$.

On ambient temperature

It is generally known that pigs are relatively susceptible to heat. HeItman et al." reported that pigs weighing $45 \mathrm{~kg}$ showed a daily weight gain of $710-900 \mathrm{~g}$ at an air temperature of $15-27^{\circ} \mathrm{C}$, but that it was reduced to $620 \mathrm{~g}$ at $32^{\circ} \mathrm{C}$. Sugahara et al. ${ }^{12}$ ) 
reported that the feed intake of pigs was markedly reduced at a temperature of $33^{\circ} \mathrm{C}$. The standard feed intake of pigs weighing $40-50 \mathrm{~kg}$ is claimed to be $1.8-$ $2.2 \mathrm{~kg}$ and their daily weight gain should be $600-650 \mathrm{~g}^{13)}$. In this study, the daily feed intake and daily weight gain of the animals in the group reared at a constant temperature of $30^{\circ} \mathrm{C}$ were $68 \%$ and $70 \%$, respectively, of the values claimed to be standard. The respiration rate was higher than the normal rate of 50-60 per min-

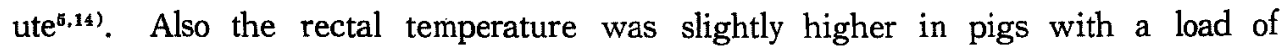
radiant heat.

This finding suggests that the productivity of pigs was already affected adversely by the environment of a constant temperature of $30^{\circ} \mathrm{C}$. Therefore, the critical temperature for decrease in the growth rate of pigs with rising environmental temperature will be between $27^{\circ} \mathrm{C}$ and $30^{\circ} \mathrm{C}$ as mentioned above.

On the index of heat stress

Holmes and CLOSE ${ }^{14}$ ) showed that respiratory rate can serve as a useful index of heat stress. Yамамото et al. ${ }^{5)}$ also reported that it was better to use the respiration rate than the rectal temperature as an information index for rearing pigs in hot environments.

On the other hand, INGRAM ${ }^{15)}$ suggested that the rectal temperature is the most useful index for pigs in high environmental temperature. Our results indicated that the respiration rate varied too widely to be used as a useful index. On the other hand, the range of rectal temperature was small and pigs with a load of radiant heat showed high rectal temperature, steadily responding to the heat stress.

From the above-mentioned findings, it was concluded that in an optimum air temperature, growing pigs will not be adversely affected by load of radiant leat.

However, in a hot environment such as the Kanto region and further southwest where the air temperature very often exceeds $30^{\circ} \mathrm{C}$, the productivity of pigs tends to be reduced.

\section{Acknowledgements}

The present work was supported by a grant-in-aid for scientific research from the Japanese Ministry of Education, Science and Culture (No. 00536019). The authors are grateful to Professor Takuma MoRita and Associate Professor Iwao NotsukI of Tokyo University of Agriculture and Technology for permission to use their environment-controlled chamber and pertinent advice.

\section{References}

1) Heitman, H. Jr., C.F. Kelly and T. E. Bond, J. Anim. Sci., 17: 62-67. 1957.

2) Mount, L. E. and D. L. Ingram, Res, Vet. Sci, 6: 84-91. 1965.

3) Bond, T.E., C. F. Kelly and H. Heitman, Jr., Anim. Prod., 9: 453-462. 1967.

4) Ingram, D. L. and I.. E. Mount, Man and Animals in Hot Environments. 1st ed. 123-145. Springer-Verlag. New York. 1975.

5) Yamamoto, S., K. Tokoro, N. Tomishima, T. Ito and K. Mimura, Jpn. J. Zootech. Sci., 42: 609-616. 1971. (in Japanese)

6) Stone, B. A. and P. A. Heap, Anim. Prod., 35: 341-351. 1982. 
7) Minowa, M., T. Yamaguchi and Y. Aihara, J. Agr. Structures Jpn., 10: 31-39. 1980. (in Japanese)

8) YoshidA, M., Design of Experiments for Animal Husbandry. 3 rd ed, 66-67. Yokendo. Tokyo. 1980. (in Japanese)

9) Yoshimoto, T., Y. Asahida, O. Koga, T. Tanaka and K. Mimura, Proc. The Vth World Conf. Anim. Prod. 2: 791-792. 1983.

10) Griffin, J. G. and T. H. Vardaman, Poult. Sci., 50: 459-463. 1971.

11) Reece, F. N., J. W. Deaton and F. W. Harwood, Trans. ASAE, 19: 733-735. 1976:

12) Sugahara, M., D. H. Baker, B.G. Harmon and A. H. Jensen, J. Anim. Sci., 31: 59-62. 1970.

13) National Research Council of Agriculture, Forestry and Fishery, Japanese Feeding Standard for Swine, 10-11. Central Association of Livestock Industry, Tokyo. 1975. (in Japanese)

14) Holmes, C. W. and W. H. Close, in Nutrition and Climatic Environment Ist ed. (Haresign, W., H. SWAN and E. LEwIs, eds.) 51-74. Butterworths. London. 1977.

15) InGram, D. L., Res. Vet. Sci., 6: 9-17. 1965.

\title{
高温環境における放射熱が育成豚の生理 反応および生産性に及ぼす影響
}

\author{
吉本 正・田中智夫 - 三村 耕
}

麻布大学獣医学部，相模原市 229

\begin{abstract}
夏季における放射熟が育成原の生理反応, 生産性に及 ぼす影響を明らかにするために，体重約 $40 \mathrm{~kg}$ のランド レース種去勢豚を用い，実験 1 では 4 頭で 35 日間，実 験 2 では, 6 頭で 21 日間試験を行なった。両実験とも， $30^{\circ} \mathrm{C}$ に調整した環境調節室に全頭を収容し, 中央に断熱 板を設置して半数ずつ 2 群に分け，一方を対照区とした. 他方には $250 \mathrm{~W}$ の赤外線ヒーターを䛲の直上からつる し， $500 \mathrm{kcal} / \mathrm{m}^{2} \cdot \mathrm{hr}$ の放射熱を 1 日 6 時間照射し，こ れを照射区とした，豚はヶージに収容し配合飼料を不断 給慨した。
\end{abstract}

その結果, 対照区の直腸温は $39.8^{\circ} \mathrm{C}$, 照射区のそれ
は 40.7 $\mathrm{C} て ゙ あ り ， 1 \%$ 水準で有意差が認められた. 呼吸 数は対照区が每分 110 回，照射区は164回であり，5\% 水準で有意美が認められた，放射熱を照射された豚は panting 状態を示した.

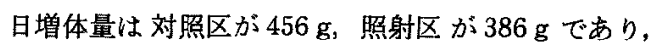
$5 \%$ 水準で有意差が認められた. 飼料要求率は対照区が 3.30，照射区が 3.90 であった。

以上の結果加ら， $30^{\circ} \mathrm{C}$ 暑熱環境は育成豚の生産性に 悪影響を及ぼすが，これに放射熱が付加された場合，生 産性が，いちじるしく低下することが認められた。

日盲会報, $55(6)$ ：416-422，1984 